\title{
PREDATION ON Biomphalaria sp. (MOLLUSCA: PLANORBIDAE) BY THREE SPECIES OF THE GENUS Belostoma (HETEROPTERA: BELOSTOMATIDAE)*
}

\author{
ARMÚA DE REYES, C. A. ${ }^{1}$ and ESTÉVEZ, A. L. ${ }^{2}$ \\ ${ }^{1}$ Facultad de Ciencias Exactas, Físicas y Naturales y Agrimensura, Universidad del Nordeste, \\ 9 de julio 1449, 3400-Corrientes, Argentina \\ ${ }^{2}$ Departamento Científico de Entomología, Museo de Ciencias Naturales La Plata, \\ Universidad Nacional de La Plata, Paseo del Bosque, s/n, 1900-La Plata, Argentina \\ Correspondence to: Ana Lia Estéves, Departamento Científico de Entomología, Museo de Ciencias Naturales La Plata, \\ Universidad Nacional de La Plata, Paseo del Bosque, s/n, 1900-La Plata, Argentina, e-mail: estevezanalia@hotmail.com \\ Received April 27, 2004 - Accepted November 25, 2004 - Distributed November 1, 2006
}

The voracious behaviour of water bugs is well known as they attack a great diversity of invertebrate and vertebrate organisms which may be of various sizes, even larger than they are (Schnack, 1976; Menke, 1979). All of the Belostomatidae family members have forelegs adapted to catch prey which are usually ambushed by bugs. After catching prey, bugs handle it in order to insert their piercing mouth parts to inject saliva and liquefy prey's tissues to suck.

The only insects that feed on snails during the larval and adult stages are belostomatids (Smith, 1997). Limnogeton Mayr, 1853 is a compulsory predator of snails (Voelker, 1968; Tawfik et al., 1978). There are few reports on members of genera Abedus Stål, 1862 and Diplonychus Laporte, 1833 preying on snails in the field or in the laboratory (Saha \& Raut, 1992; Tawfik et al., 1978; Okada \& Nakasuji, 1993; Smith, 1997). Somasundarao (1963), Voelker (1968) and Saha \& Raut (1992) suggested the importance of these bugs as useful snails control agents to eradicate severe worm diseases. Pointier \& Delplanque (1976) pointed out the importance of $B$. boscii as a $B$. glabrata predator in Guadeloupe and Kesler \& Munns (1989) cited B. flumineum as an important cause of snails' mortality in the U.S.A.

Little is known about the alimentary preference of Belostoma species under laboratory conditions. Several authors fed immature and adult stages of Belostoma species with varied prey for different purposes: Kehr \& Schnack (1991) fed B. oxyurum Dufour 1863 with tadpoles; Armúa \&
Estévez (1997) fed immature stages of B. elegans Mayr with mosquito larvae, small crustacean as Daphnia sp. and Hyalella sp., and tadpoles. Some species of Belostoma Latreille, 1807 have occasionally been observed feeding on snails such as B. malkini (Cullen, 1969). Pereira \& Melo (1998) fed specimens of B. plebejum and B. anurum under laboratory conditions, with Culex quinquefasciatus, Daphnia sp. and Biomphalaria glabrata and both species fed on all offered prey but they showed preference for mosquito larvae; B. micantulum was fed with larvae and pupae of Aedes fluviatilis and Biomphalaria glabrata, showing preference for mosquitoes in all stages (Consoli et al., 1989).

Presented herein is an experimental study with Biomphalaria sp. as prey for specimens of the genus Belostoma. The selected species, included in the three size categories proposed by Lauck (1962), B. micantulum (small species), B. elegans (medium species) and $B$. elongatum (moderately large species) show different structural characteristics on their heads. The aim of this work is to compare the ability of each species with snails according to the head morphological features.

\section{MATERIAL AND METHODS}

During March and April, 1997 specimens of B. micantulum, B. elegans, B. elongatum, together with snails of the genus Biomphalaria were captured with a net in a pond close to Santa Ana, Corrientes province, Argentina.

Ten specimens of the selected Belostoma species were put into individual vials with tap

* This work was developed with a grant from Secretaría de Ciencia y Técnica de la Universidad del Nordeste, Corrientes, Argentina. 
water and Elodea sp. as a substrate at a laboratory. After two days with no food supply, two snails were offered to each bug as the unique food source. Snails were selected by their size, small snails ( $2 \mathrm{~mm}$ in diameter) were offered to B. micantulum; medium size (3-5 $\mathrm{mm})$ to B. elegans and those of a large size ( $6 \mathrm{~mm}$ or more) to $B$. elongatum.

They were observed every 24 h over 5 days in order to replace the eaten snails (emptied shells) by a new stock of snails. This procedure was replicated 6 times. Belostoma specimens and snails were replaced by recently captured specimens when each experiment started. The results are shown as a percentage of eaten snails and a percentage of bugs which ate snails.

\section{RESULTS AND DISCUSSION}

B. micantulum used snails as resting support most of the time, piercing shells on all its surface; there were one or two ingested snails in 4 experiments representing $6 \%$ of the total offered snails $(n=120) ; 85 \%$ of the bugs did not feed on snails.

The B. elegans behavior was similar to B. micantulum; empty shells were found in all the experiments, which represented $16 \%$ of the total offered snails $(n=124) ; 71 \%$ of the bugs did not feed on snails.

B. elongatum showed a different behavior to that of the above mentioned species. When the prey was offered it was instantly seized with its fore legs. Bugs of this species handled the snail, aiming to direct the opening of the shell in front of the beak, inserting it immediately into the snail's body. Bugs maintained this position during 45 to $60 \mathrm{~min}$ before releasing the empty shell. Bugs carrying prey were able to go around inside the vials. Snails were eaten in all the experiments, $76 \%$ of the offered snails were eaten $(n=193)$; only $3 \%$ of bugs did not eat Biomphalaria sp.

Small species such as $B$. micantulum have a short anteoculus and a short and stout beak. This species rejected Biomphalaria sp. diet. This species failed to introduce the stilettos properly into the snail's shell due to characteristics of the head morphology.

Medium size species such as $B$. elegans showed a certain ability to catch and feed on Biomphalaria sp. Medium sized species heads are characterized by having anteoculus which are slightly longer than their interoculus and a long and slender beak.

B. elongatum showed a great ability to catch and feed on snails. This moderately large species has anteoculus longer than interoculus and its beak is long and slender.

Although few observations on Belostoma species predatory ability on snails have been made, we are able to assume on the basis of literature and this experimental study, that medium and moderately large or large Belostoma species showed a remarkable preference for snails as a food source. These groups of species are successful in preying on snails due to the specialized characteristics of their heads such as the presence of anteoculus which is longer than their interoculus and a slender and long beak, enabling the styletes to be inserted deeper into the shells thus reaching the retracted body of Biomphalaria. The effectiveness of Belostoma species preying on snails needs to be studied in the field in order to know if these insects' populations may have a controlling effect on snails' populations.

\section{REFERENCES}

ARMÚA DE REYES, A. C. \& ESTÉVEZ, A. L., 1997, Observaciones biológicas de los estadíos preimaginales de B. elegans Mayr en condiciones controladas. FACENA, (Corrientes), 13: 141-143.

CONSOlli, R. A. G. B., PEREIRA, M. H., MELO, A. L. \& PEREIRA, L. H, 1989, Belostoma micantulum Stål 1858 (Hemiptera: Belostomatidae) as a predator of larvae and pupae of Aedes fluviatilis (Diptera: Culicidae) in laboratory conditions. Memorias do Instituto Oswaldo Cruz, (Rio de Janeiro), 84: 577-578.

CULLEN, M. J., 1969, The biology of giant bugs (Hemiptera: Belostomatidae) in Trinidad. Proceedings of Royal Entomological Society. London (A), 44: 7-9.

KESLER, D. H. \& Munns Jr., W. R., 1989, Predation by Belostoma flumineum (Hemiptera): an important cause of mortality in freshwater snails. J.N. Amer. Benthol. Soc., 8: 342-350.

KHER, A. I. \& SCHNACK, J.A., 1991, Predator prey relationship between giant water bugs (Belostoma oxyurum) and larval anurans (Bufo arenarum). Alytes, (Paris), 9: 61-69.

LAUCK, D., 1962, A monograph of the genus Belostoma (Hemiptera). Part I. Introduction and B. dentatum and subspinosum groups. Bulletin of the Chicago Academy of Science, 11(3): 34-81

MENKE, A. S., 1979, Family Belostomatidae, pp. 76-86. In: Menke A. S. (editor), The semiaquatic and aquatic 
Hemiptera of California. Bulletin of the California Insect Survey, 21: 1-166.

OKADA, H. \& NAKASUJI, F., 1993, Comparative studies on the seasonal occurrence, nymphal development and food menu in two giant water bugs Diplonychus japonicus Vuillefroy and D. major Esaki (Hemiptera: Belostomatidae). Res. Pop. Ecol., (Kyoto), 35: 15-22.

PEREIRA, M. \& MELO, A. L., 1998, Influência do tipo de presa no desenvolvimento e na preferência alimentar de Belostoma anurum Herrich-Schåffer, 1848 e B. plebejum Stål, 1858 (Heteroptera: Belostomatidae). In: J. L. Nessimian, \& A. L. Carvalho (eds.), Ecologia de Insetos aquaticos. Serie Oecologia Brasiliensis, (Rio de Janeiro), v. 41-49.

POINTIER, J. P. \& DELPLANQUE, A. 1976, Les predateurs de Biomphalaria glabrata (Say, 1818). Mollusque vecteur de la Schistosomose en Guadeloupe. Bull. Soc. Sci. Vét. Med. Comp. (Lyon), 78: 319-331.

SAHA, T. C. \& RAUT, S. K., 1992, Bioecology of the water bug Sphaerodema annulatum Fabricius (Heteroptera: Belostomatidae). Arch. Hydrobiol., 124: 239-253.
SCHNACK, J. A., 1976, Insecta Hemiptera. Belostomatidae. Fauna Argentina de Agua Dulce Rep. Arg., (Buenos Aires), 35, Fasc. 1: 66.

SMITH, R. L., 1997, Evolution of paternal care in the giant water bugs (Heteroptera: Belostomatidae). In: J. C. Choe and B. J. Crespi (eds.), Social Behavior in Insects and Arachnids. Cambridge, University Press, 16: 149.

SOMASUNDARAO, G., 1963, A preliminary note on the biological control of freshwater snails by aquatic insects. Indian.Vet. J., (Madras), 40: 50.

TAWFIK, M. F. S., EL-SHERIF, S. I. \& LUTFALLAH, A. F., 1978, On the life history of the giant water bug Limnogeton fieberi Mayr. (Hemiptera: Belostomatidae), predatory on some harmfull snails. Zool. Anz. (Jena), 86: 138-145.

VOELKER, J., 1968, Untersuchungen zu Ernährung, Fortpflanzungsbiologie und Entwicklung von Limnogeton fieberi Mayr (Belostomatidae: Hemiptera) als Beitrag zur Kenntnis von natürlichen Feinden tropischer Sußwasserschnecken. Entomol. Mitt. Zool. Staatsinst. Zool. Mus. Hamb., 3: 1-24. 
